\title{
A Selective Technique for the Isolation of Neurospora crassa from Soil
}

\author{
By RAMESH MAHESHWARI AND A. ANTONY \\ Department of Biochemistry, Indian Institute of Science, \\ Bangalore-560012, India
}

(Received 23 July 1973; revised 3 December 1973)

\section{INTRODUCTION}

Neurospora is among the most studied of all eukaryotes. It is a convenient organism for the study of genetic polymorphism through analysis of isozymes (Yu, Garrett \& Sussman, I97I ; Reddy \& Threlkeld, I97 I, I972), and the possibility of population studies with Neurospora has been demonstrated by Perkins (1970) who collected isolates from over 60 localities in the tropics. However, Perkins' collection was derived from visibly growing colonies on vegetation or upon the soil surface in burned areas, so selection of certain forms may have occurred. To be more representative of the potential genetic variability in nature, collections should include samples from a diversity of soil habitats. We report here on a technique found effective for the isolation of Neurospora crassa from soils in India.

\section{METHODS}

The soil samples analysed were collected from over 30 localities in Mysore, Goa and Delhi during $1972-3$. About $500 \mathrm{~g}$ of soil from a $30 \times 30 \mathrm{~cm}(\mathrm{I} \times \mathrm{Ift})$ area were removed from the upper 7.5 to $10 \mathrm{~cm}$ layer and packaged in polythene bags. These were stored at $7^{\circ} \mathrm{C}$ or at room temperature until use, one to six months later. Soil ( 3 to $5 \mathrm{~g}$ ) was suspended in $\mathrm{IO} \mathrm{ml} \mathrm{IO}^{-3} \mathrm{M}$-furfural and heated to $60^{\circ} \mathrm{C}$ for $30 \mathrm{~min}$. The liquid was then removed by low-speed centrifugation and portions of soil were plated in several Petri dishes containing Vogel's $\mathrm{N}$ medium (Davis \& de Serres, 1970) acidified to $\mathrm{pH} 4.0$ immediately before use with I $\mathrm{N}-\mathrm{HCl}$ to prevent bacterial growth. The Petri dishes were incubated under fluorescent light in a chamber at room temperature which ranged from 20 to $30^{\circ} \mathrm{C}$.

Crosses were made in test tubes on Westergaard and Mitchell's crossing medium (Davis $\&$ de Serres, 1970) containing filter paper strips as the carbon source. The protoperithecial parent was inoculated 5 to 7 days before fertilization by conidia from the other parent. For compatibility and fertility tests, the standard strains shown in Table I (obtained from Fungal Genetics Stock Center) were used as protoperithecial parents.

\section{RESULTS AND DISCUSSION}

The isolation procedure described yielded Neurospora crassa from two only of over 30 soil samples screened. One of these was collected from a coconut plantation having an undergrowth of grass and Mimosa sp., situated on the banks of a river in Goa, and it was dark brown and clayey with a $\mathrm{pH}$ of 5.0 . The other sample, which was black, clay loam rich in humus, with a $\mathrm{pH}$ of $7 \cdot 0$, was collected from the shady slopes of a hill near Bangalore covered with a thick growth of shrubs, at an altitude of $1200 \mathrm{~m}$. 
Table I. Standard strains used in compatibility and fertility tests

\begin{tabular}{rllcc}
$\begin{array}{c}\text { FGSC } \\
\text { no. }\end{array}$ & \multicolumn{1}{c}{ Locus } & $\begin{array}{c}\text { Allele } \\
\text { (isolation no.) }\end{array}$ & $\begin{array}{c}\text { Mating } \\
\text { type }\end{array}$ & $\begin{array}{c}\text { Linkage } \\
\text { group }\end{array}$ \\
987 & w.t. (St Lawrence) & 74-OR23-IA & A & - \\
988 & w.t. (St Lawrence) & $74-$ OR8-1a & a & - \\
45 & fl & L & A & IIR \\
46 & $\mathrm{fl}$ & $\mathrm{L}$ & $\mathrm{a}$ & IIR \\
$\mathrm{I} 838$ & $\mathrm{fl}$ & $\mathrm{fl}^{\mathrm{p}}$ & $\mathrm{A}$ & IIR \\
$\mathrm{I} 690$ & $\mathrm{fl}$ & $\mathrm{fl}^{\mathrm{p}}$ & $\mathrm{a}$ & IIR
\end{tabular}

w.t. $=$ wild type; $f l=$ fluffy; $f^{p}=$ fluffy, $p H$-sensitive allele.

Table 2. Germination of ascospores from crosses of wild Neurospora crassa isolates from soil

Spores were germinated in distilled water on a reciprocal shaker for $24 \mathrm{~h}$ at room temperature. Germination counts were based on at least I00 spores.

\begin{tabular}{lc}
\multicolumn{1}{c}{ Treatment } & Germination $(\%)$ \\
Control & Nil \\
Heat-shock at $60^{\circ} \mathrm{C}$ for $30 \mathrm{~min}$ in water & 80 \\
Heat-shock at $60^{\circ} \mathrm{C}$ for $30 \mathrm{~min}$ in $10^{-3} \mathrm{M}$-furfural & $8 \mathrm{I}$ \\
$10^{-3} \mathrm{M}$-Furfural for $30 \mathrm{~min}$ & 76 \\
$65 \%$ ethanol for $15 \mathrm{~min}$ & 12 \\
As above+heat-shock at $60^{\circ} \mathrm{C}$ for $30 \mathrm{~min}$ in water & 24
\end{tabular}

When present, Neurospora crassa spread over other fungi and completely covered the plates in 48 to $72 \mathrm{~h}$. It was readily identified by its pink masses of loose conidia on hyphae growing away from the agar and by its tendency to creep out of the Petri dish. These isolates resembled wild-type strains of $N$. crassa morphologically and their identity was confirmed by crossing with the standard strains of $N$. crassa. Crosses with the $\mathrm{fl}^{\mathrm{p}}$ isolates produced the most perithecia. Both mating types were found with equal frequency in colonies isolated from the same soil sample. This is to be expected if Neurospora reproduces sexually in nature and colonies are derived from randomly mixed ascospores. The isolates from nature (wild isolates) were not equally fertile as judged by the number of perithecia produced when crossed with the standard strains. Crosses among wild isolates also differed in fertility, but produced viable ascospores which germinated only when heat-shocked or treated with furfural or ethanol.

The alcohol-treatment technique ('soil pasteurization') devised by Warcup \& Baker (I963) and used in Wisconsin, U.S.A. to isolate some new species of Neurospora from soil (Nelson, Novak \& Backus, I964; Mahoney, Huang \& Backus, 1969) was also tested. We found treatment of soil with $65 \%(\mathrm{v} / \mathrm{v})$ ethanol for $\mathrm{I} 5 \mathrm{~min}$ followed by heating to $60{ }^{\circ} \mathrm{C}$ for $30 \mathrm{~min}$ in water or in $10^{-3} \mathrm{M}$-furfural more effective than alcohol treatment alone for obtaining $N$. crassa, but again only from the two soils mentioned above. When these soils containing $N$. crassa were used to compare the relative effectiveness of the alcohol, alcohol theat, or furfural theat treatments, we found the last yielded Neurospora more frequently. Thus, Neurospora appeared in Petri dishes with a frequency of o to $5 \%$ with alcohol treated soil, Io to $20 \%$ with alcohol + heat treated soil, and 20 to $40 \%$ with furfural theat treated soil. These results are corroborated by tests with ascospores (Table 2). When soil was used untreated or was heated to $60{ }^{\circ} \mathrm{C}$ in a moist chamber, Neurospora was not obtained even from those soils known to contain it. Although we generally used Vogel's medium, trials with 
some soils were repeated with Czapek's medium supplemented with biotin, with corn meal agar, or with a glucose-asparagine medium (Gochenaur, I964) used by workers in Wisconsin to isolate Neurospora from tropical soils. From the results, availability of ingredients, and convenience in preparation of the media, we consider Vogel's medium is better.

Hitherto there has been no evidence that $N$. crassa reproduces sexually in nature (Prakash, I965; and cf. Neurospora Newsletter No. I6, I970, p. 9). The fact that we could isolate compatible mating types in equal frequency from soil removed from a single site by using treatments known specifically to activate dormant ascospores of Neurospora (Sussman, I969) suggests that this species reproduces sexually under natural conditions.

This is the first time Neurospora has been isolated from soils in India, although Perkins (1970) had collected this organism from visibly growing colonies on burnt vegetation in India and a new species was recently described from soil in Pakistan (Frederich, Vecker \& Benjamin, 1969).

We thank Professor A. S. Sussman, University of Michigan, for useful suggestions, Dr V. N. Vasantharajan for discussions, and M. Maheshwari for assistance.

\section{REFERENCES}

Davis, R. H. \& DE Serres, F. J. (1970). Genetic and microbiological research techniques for Neurospora crassa. Methods in Enzymology 17, 79-143.

Frederich, L., Vecker, F. A. \& Benjamin, C. R. (1969). A new species of Neurospora from soil of West Pakistan. Mycologia 61, I077-1084.

GochenAur, S. E. (1964). A modification of the immersion tube method for isolating soil fungi. Mycologia 56, $92 \mathrm{I}-923$.

Mahoney, D. P., HuAng, L. H. \& Backus, M. P. (1969). New homothallic Neurosporas from tropical soils. Mycologia 6r, 264-272.

Nelson, A. C., Novak, R. O. \& Backus, M. P. (1964). A new species of Neurospora from soil. Mycologia 56, 384-392.

Perkins, D. D. (1970). Genetics of Neurospora populations collected from nature. In Year Book of the American Philosophical Society, pp. 333-334.

Prakash, V. (1965). Sexual reproduction of Neurospora in nature. Neurospora Newsletter 7, 5-6.

Reddy, M. M. \& Threlkeld, S. F. H. (197I). Genetic studies of esterase isozymes in Neurospora. I. A study of eight species. Canadian Journal of Genetics and Cytology 13, 298-305.

Reddy, M. M. \& Threlkeld, S. F. H. (1972). Genetic studies of isozymes in Neurospora. II. Esterases. Canadian Journal of Genetics and Cytology 14, 527-53I.

Sussman, A.S. (1969). The dormancy and germination of fungus spores. Symposium of the Society for Experimental Biology 23, 99-121.

WARCUP, J. H. \& BAKER, K. F. (1963). Occurrence of dormant ascospores in soil. Nature, London r97, $1317^{-1} 318$.

Yu, S. A., Garretr, M. K. \& Sussman, A. S. (197I). Genetic control of multiple forms of trehalase in Neurospora crassa. Genetics $68,473-48 \mathrm{I}$. 